\title{
Purification, partial characterization and antimicrobial activity of Lectin from Chenopodium Quinoa seeds
}

\author{
Dávia Guimarães POMPEU ${ }^{1}$, Marcelo Augusto MATTIOLI², Rosy Iara Maciel de Azambuja RIBEIRO${ }^{1}$, \\ Daniel Bonoto GONÇALVES ${ }^{1}$, Juliana Teixeira de MAGALHÃES ${ }^{1}$, Sérgio MARANGONI², \\ José Antônio da SILVA ${ }^{1}$, Paulo Afonso GRANJEIRO ${ }^{1 *}$
}

\begin{abstract}
A novel lectin was isolated from the seeds of Chenopodium quinoa. To achieve this end, the crude extract from the quinoa was submitted to two purification steps, Sephadex G50 and Mono Q. The hemagglutinating activity showed that this lectin agglutinates human erythrocytes. Its activity is inhibited by glucose and mannose, and remained stable under a wide range of $\mathrm{pH}$ levels and temperatures. The quinoa lectin was found to be a heterodimeric lectin of approximately $60 \mathrm{kDa}$, consisting of two subunits of approximately $25 \mathrm{kDa}$ and $35 \mathrm{kDa}$. This lectin had its antimicrobial activity tested against several bacteria strains and effectively inhibited three strains. These strains were all Gram-negative, making this lectin a promising antimicrobial tool.
\end{abstract}

Keywords: antimicrobial; Chenopodium quinoa; glucose/mannose-specific; lectin; seeds.

Practical Application: The purification and characterization of this novel lectin allow its study for a diversity of applications such as antibacterial, anticancer, anti-inflammatory and biotechnology and its further use as drugs for human diseases.

\section{Introduction}

Lectins are oligomeric carbohydrate-binding proteins that are involved in various biological recognition processes (Ghosh \& Mandal, 2012). They are a large and diverse group of proteins that have the ability to bind reversibly to monosaccharides and oligosaccharides, which can be defined as a class of structurally diverse proteins or glycoproteins (Sharon, 2008). These proteins are widely distributed in nature, being found in microorganisms (Visini et al., 2015), animals (Lundbo et al., 2015) and plants (Silva et al., 2007).

More than a hundred lectins have been isolated and characterized to varying degrees, primarily in seeds. However, the structural diversity of these proteins requires further studies to improve the understanding of their different molecular properties, biochemical and functional. This would allow for a wider application of lectins as tools in various fields (immunological, biochemical and biotechnological), especially those that exploit the protein-carbohydrate interaction. The ability of certain lectins to distinguish between different cell types has encouraged and justified the purification and characterization of lectins originating from various species (Silva et al., 2007).

It is unlikely that all of the functions and applications of lectins have been identified. Their easy occurrence, their high thermal stability and mainly, their well-defined carbohydrate binding properties are important tools in the field of glyco-science, immunology and biotechnology, healthcare and pharmaceutical industries as biochemical tools for different studies (Nasi et al., 2009).
Their ability to reversibly bind to a specific saccharide has attracted the attention of scientists. Each lectin has a characteristic sugar-binding specificity profile indicating that they are able to recognize different glycotopes (Kamiya et al., 2012). Based on the specificity of the sugar bound, plant lectins are classified into groups, such as Gal/GalNAc-specific, glucose/mannose-specific, fucose specific, GlcNAc specific, and sialic acid specific lectins (Goldstein \& Poretz, 1986). Since mannose is widespread in animals, insects and microorganisms, mannose-binding lectins are considered biologically important proteins (Wong et al., 2008).

Despite their differences in specificity for carbohydrates, lectins are similar relative to their physicochemical properties. They are usually composed of two or four subunits with molecular weights of $25-45 \mathrm{kDa}$, each one with a carbohydrate-binding site (Nasi et al., 2009). C-type lectins present only homodimers linked by disulfide bonds (Arlinghaus \& Eble, 2012).

The physiological function of plant lectins has not been openly proved. It is understood that the lectins are responsible for the plant defense and specific protein-carbohydrate interaction mediators within the plant cells (Ahmad et al., 2011).

Many plants produce seeds that are rich in protein and carbohydrates and therefore are commonly infested by pests (Coelho et al., 2010). Lectins are a potential type of molecule candidate for controlling pests and diseases (Araújo-Filho et al., 2010). The mechanisms of recognition involve specific interactions between the protein receptors and saccharide residues (Lee \& 
Peng, 2012). The lectins that bind to accessible carbohydrate residues from the cell wall or cell membrane trigger a cascade of biological responses.

The capacity for identifying and binding glycoconjugates from the microorganism's surface is exclusive to lectins. Consequently, they are capable of inhibiting the motility and multiplication of microorganisms (Oliveira et al., 2007). The interaction between carbohydrates and lectins act in many biological processes, and intermediate a wide range of activities, including bacterial and fungal growth inhibition (Klafke et al., 2013).

The pseudo cereal Chenopodium quinoa was originally cultivated in Peru, Bolivia, Equator, Chile and Argentina at various latitudes and altitudes (Bhargava et al., 2006; Pesoti et al., 2015). Due to its potential as a food source and the limited production in South America, quinoa is now being introduced in Europe, North America, Africa and Asia (Bhargava et al., 2006). This has contributed to its popularization, especially in developing countries, as an alternative food source. It is an important food source considering its high nutritional content, in addition to its high levels of essential amino acids (Silva et al., 2015).

There is abundant literature on legume lectins, however, there have been a lack of studies regarding cereal lectins. There was a corn grain study (Molina et al., 2004) where the lectin was characterized, but this is one of only a few available examples using cereal seeds.

The purpose of this article is to describe the purification process and partial characterization of a novel cereal lectin from Chenopodium quinoa seeds, in addition to showing its antimicrobial activity.

\section{Materials and methods}

\subsection{Extraction and protein purification}

Chenopodium quinoa seeds, donated by Embrapa, were pulverized to obtain a finely powdered material. For the extraction, the protein flour was diluted in $0.1 \mathrm{M}$ saline solution with a $\mathrm{pH}$ of $7.6($ rate of 1:5 $(\mathrm{w} / \mathrm{v}))$ before being placed under stirring for one hour at $25{ }^{\circ} \mathrm{C}$. The supernatant was recovered using centrifugation ( $3500 \mathrm{rpm}$ for 30 minutes) (Fanem, Excelsa II $206 \mathrm{BL}, \mathrm{Brazil})$, and was then dialyzed against ultrapure water before being lyophilized (Liotop, L101, Brazil).

First, the supernatant (herein referred to as $\mathrm{CqCE}$ [Chenopodium quinoa crude extract]) was diluted $(0.3 \mathrm{mg} / 3 \mathrm{~mL})$ in $0.2 \mathrm{M}$ Ambic buffer with a $\mathrm{pH}$ of 7.6. The volume of $3 \mathrm{~mL}$ of this solution was then chromatographed on a Sephadex G-50 equilibrated with $0.2 \mathrm{M}$ Ambic buffer with a $\mathrm{pH}$ of 7.6, under a flow of $0.5 \mathrm{~mL} / \mathrm{min}$ ( $3 \mathrm{ml} /$ tube), using a Fast Protein Liquid Chromatography system (FPLC) (BioRad BioLogic LP, USA). The fractions collected had an absorbance of $280 \mathrm{~nm}$. After chromatography, two different fractions were recovered. These two fractions were clearly separated by two peaks, called Peak 1 and Peak 2. Both peaks were lyophilized (Liotop, L101, Brazil) and stored in a freezer at $-20^{\circ} \mathrm{C}$.
Peak 1, which had shown hemagglutinating activity, was submitted to an ion exchange chromatography. It was dissolved in Tris- $\mathrm{HCl} 20 \mathrm{mM} \mathrm{pH} 8.0$ buffer and applied $(1 \mathrm{~mL})$ to an ion exchange column (MonoQ-GE) previously equilibrated with a Tris- $\mathrm{HCl} 20 \mathrm{mM} \mathrm{pH} 8.0$ buffer. Fractions of $3.0 \mathrm{~mL}$ were collected and monitored at $280 \mathrm{~nm}$ in a FPLC system (BioRad BioLogic LP, USA). The binding protein was eluted after the application of Tris- $\mathrm{HCl} 20 \mathrm{mM}+\mathrm{NaCl} 500 \mathrm{mM} \mathrm{pH}$ 8.0. Both peaks were tested and, the one that had shown HA was then dialyzed against the Tris- $\mathrm{HCl}$ buffer $10 \mathrm{mM}$ and then lyophilized (Liotop, L101, Brazil) and stored in a freezer at $-20^{\circ} \mathrm{C}$.

The protein content was verified using the Bradford Method (Bradford, 1976) and hemagglutinating activity, according to Sharon \& Lis (1972). The results from the hemagglutinating activity were expressed as Hemagglutinating Units (HU), which were calculated as the inverse of the highest dilution, presenting hemagglutination per $50 \mu \mathrm{L}$ (HU. $50 \mu \mathrm{L}^{-1}$ ).

\section{Determination of hemagglutinating activity}

The hemagglutinating activity was tested on intact and trypsinized human erythrocytes of the ABO-human blood system. The collected blood was kept in a saline solution containing EDTA, following Sharon \& Lis's (1972) method. The blood was centrifuged at room temperature in a table centrifuge (Eppendorf, Eppendorf centrifuge 5417, USA) at $450 \mathrm{rpm} \times \mathrm{g}$ for $10 \mathrm{~min}$. Then, the supernatant was rejected and the cell pellet (erythrocytes) was washed 4-5 times with $0.15 \mathrm{M} \mathrm{NaCl}$ at a rate of $5 \mathrm{~mL}$ of $\mathrm{NaCl}$ for each $\mathrm{mL}$ of sedimented erythrocytes. For one $\mathrm{mL}$ of washed erythrocytes, $25 \mathrm{~mL}$ of PBS was added. For each 10 parts of this suspension, a part of the trypsin solution at $1 \% \mathrm{w} / \mathrm{v}$ was added before being incubated at $37^{\circ} \mathrm{C}$ for 1 hour. The trypsinized erythrocytes were washed $4-5$ times with $0.15 \mathrm{M}$ $\mathrm{NaCl}$ to remove the enzyme. The erythrocytes, intact and trypsinized, were finally resuspended in a TBS- $\mathrm{Ca}^{2+}$ buffer to reach the final concentration of $2 \%$ of the erythrocytes.

To determine the hemagglutinating activity of the fractions extracted from the quinoa, microtiter plates of 96 wells were used. In this step, $50 \mu \mathrm{L}$ of the sample was added to the wells of the first column, and the following wells were serially diluted. After the dilutions, $50 \mu \mathrm{L}$ intact or trypsinized erythrocytes solution at $2 \%$ were added to all wells. The wells of column 12 containing only the TBS- $\mathrm{Ca}^{2+}$ solution and erythrocytes were considered controls. Over the course of two hours, the plates were incubated at $37^{\circ} \mathrm{C}$, and at the end of this period, the minimum concentration of the sample showing hemagglutinating activity was observed.

\section{Affinity for carbohydrate test}

The test for inhibition of hemagglutinating activity of the carbohydrates was performed using agar agar, agarose, corn starch, cellulose, fructose, fucose galactose, glucose, glucosamine, gum arabic, lactose, maltose, mannitol, mannose, methyl- $\alpha$-piranoside, pectin, raffinose, ribose and sucrose. In the first row of wells of the microtiter plates, $50 \mu \mathrm{L}$ of carbohydrate were added in an initial concentration of $100 \mathrm{mM}$. The carbohydrates were serially diluted with $50 \mu \mathrm{L}$ of $\mathrm{TBS}^{-\mathrm{Ca}^{2+}}$ already present in the plate 
wells. Thereupon, $50 \mu \mathrm{L}$ of sample was added to each well for a final concentration of $9.0 \mathrm{mg} / \mathrm{mL}$. The plates were kept at room temperature for 30 minutes before $50 \mu \mathrm{L}$ of a $2 \%$ suspension of trypsinized type A human erythrocyte was added. After two hours, the lowest concentration of carbohydrate that was able to inhibit agglutination of erythrocytes at $37^{\circ} \mathrm{C}$ was determined. Columns 11 and 12 were considered controls, where the negative controls (no HA) consisted of a $50 \mu \mathrm{L}$ carbohydrate solution and $50 \mu \mathrm{L}$ of cell suspension, and the positive (HA) consisted of $50 \mu \mathrm{L}$ of lectin and $50 \mu \mathrm{L}$ of suspension of erythrocytes.

\section{Chelating agents action on the hemagglutination activity}

Next, $50 \mu$ EDTA ( $25 \mathrm{mM}$ ) was added and subsequently serially diluted in TBS-Ca ${ }^{2+} 25 \mu \mathrm{L}$, which was already, present. Then, $25 \mu \mathrm{L}$ of a solution containing lectin was added, followed by a $50 \mu \mathrm{L}$ of cell suspension trypsinized human type A erythrocytes $2 \%$ in TBS- $\mathrm{Ca}^{2+}$. The control, in column 12 , contained $25 \mu \mathrm{L}$ of the lectin solution, $25 \mu \mathrm{L}$ of TBS- $\mathrm{Ca}^{2+}$ and $50 \mu \mathrm{L}$ of the cell suspension.

\section{Denaturing the agent's action on the hemagglutination activity: pH}

Aliquots of lectin were separated in microtubes, concentrated in a Speed Vac, and resuspended in buffers with $\mathrm{pH}$ varying from 2.0 to 10.0. They were then incubated in a water bath at $37^{\circ} \mathrm{C}$ for one hour. After this period, they were removed and balanced with $\mathrm{NaOH}$ or $\mathrm{HCl}$ until the $\mathrm{pH}$ stabilized between 7.0 and 8.0. Then, the hemagglutination assay was used to test the samples. The activity was compared to the control that had been prepared with the lectin diluted in TBS-Ca ${ }^{2+}$.

\section{Denaturing agent's action on the hemagglutination activity: thermal stability}

The stability test of the lectin at different temperatures was performed in a water bath at a range of $37^{\circ} \mathrm{C}$ to $100^{\circ} \mathrm{C}$ for a period of 30 minutes. After stopping the trial with an ice bath, the samples were analyzed for their hemagglutinating activity using human type A erythrocytes. The control was done at a rate that remained at room temperature.

\subsection{Characterization of the lectin}

\section{Electrophoresis under denaturing conditions}

The electrophoresis for the polyacrylamide-sodium dodecyl sulfate (SDS-PAGE) was prepared using $12.5 \%$ running gel and a gel separation of $5 \%$. The samples (10-50 mg protein) were dissolved in a sample buffer (1.0 M Tris- $\mathrm{HCl} \mathrm{pH} \mathrm{6.8,} \mathrm{Bromophenol}$ Blue, glycerol, 20\% SDS, ultrapure water) with and without DDT. The electrophoretic run was carried out at room temperature in a running buffer of Tris- $\mathrm{HCl} / \mathrm{Glycine} 0.025 \mathrm{M}$, which lasts approximately three hours in a current of $25 \mathrm{~mA}$ (Biorad, Mini Protean, USA).

After the run, the gel was removed from the plates and placed in a solution containing coomassie blue R-250 0.25\% in acetic acid, methanol and water (10:40:50) for protein staining. A process of washing in acetic acid, methanol, and water was used to destain the gel and remove excess die, helping with the visualization of the protein bands (10:40:50). Finally, the molecular weight was determined using molecular mass references.

\section{Native acidic electrophoresis}

The native electrophoresis under acidic conditions was performed using $12.5 \%$ running gel and stacking gel 5\%. The sample was resuspended in the sample buffer $((\mathrm{KOH}-1 \mathrm{M}$; glacial acetic acid; ultrapure water; $\mathrm{pH}$ 6.8), glycerol, basic fuchsin, ultrapure water).

The electrophoretic run (Biorad, Mini Protean, USA) was performed at room temperature in $1 \mathrm{X}$ running buffer glacial acetic acid/alanine at a $\mathrm{pH}$ of 4.3. Initially, a pre-race was performed under a constant current of $1.0 \mathrm{~mA}$, lasting approximately one hour. Subsequently, the electrodes were reversed under constant voltage. The final race was indicated by the arrival of a basic fuchsin marker in the middle of the plate.

After the run, the gel was stained using Coomassie blue R-250 0.25\% methanol, acetic acid and ultrapure water (40:10:50). The bleaching gel to remove excess dye and visualization of the protein bands was effected by washing it in methanol, acetic acid and ultrapure water (40:10:50).

\subsection{Antimicrobial activity}

The antimicrobial activity was conducted using 11 strains of bacteria, seven of which were gram negative (Escherichia coli ATCC 11229, Pseudomonas aeruginosa ATCC 25619, Proteus vulgaris ATCC 13315, Salmonella enterica ATCC 10708, Klebsiella pneumoniae ATCC 4352, Serratia marcescens ATCC 14756 and Enterobacter cloacae ATCC 39978) and, four of which were gram positive (Staphylococcus aureus ATCC 29213, Enterococcus faecallis ATCC 19433, Micrococcus luteus ATCC 53598, Staphylococcus epidermidis ATCC 12228). The microorganisms were activated in Mueller-Hinton broth after 24 hours of incubation and a groove was made for isolating the colonies. The cell number standardization was done using the tube number 0.5 from the McFarland scale, which corresponds to $1.5 \times 10^{8}$ cells, followed by two serial dilutions ( $1 \mathrm{~mL}$ broth with cells in $9 \mathrm{~mL}$ of saline) in order to reach the concentration of $10^{6}$ cells. Then, the microorganisms were inoculated in petri dishes containing Mueller-Hinton agar. Three concentrations of the lectin were tested $(100 \mu \mathrm{g} / \mathrm{mL}, 250 \mu \mathrm{g} / \mathrm{mL}$ and $500 \mathrm{mg} / \mathrm{mL})$. The control was the buffer used to dilute the proteins (20 mM Tris- $\mathrm{HCl} \mathrm{pH8.0)}$. Approximately $10 \mu \mathrm{L}$ of each concentration of C. quinoa lectin was added to the agar's surface. The plates were incubated for 24 hours at $37^{\circ} \mathrm{C}$.

\subsection{Statistical analysis}

Data were analyzed using a one-way analysis of variance (ANOVA) (General Linear Models). A Tukey test was used to identify the means that differed when the ANOVA indicated statistical significance. For this test, $p$ values $<0.05$ were considered significant. All the experiments were done triplicated. 


\section{Results}

\subsection{Purification of C. quinoa lectin}

The sample was applied to a column of size exclusion Sephadex G-50, which separated the proteins by different molecular weights. The presence of three protein peaks was observed (Figurela). Hemagglutinating tests for both peaks revealed that only the first was able to cause erythrocyte hemagglutination.

The sample contemning the first peak from Sephadex G-50 chromatography was applied to an ion exchange column (MonoQ), in which two protein fractions were detected: One that did not bind to the resin and the other that was eluted after a saline solution (Tris- $\mathrm{HCl} 20 \mathrm{mM}+\mathrm{NaCl} 500 \mathrm{mM}$ ) (Figure1b). The first peak, which demonstrated hemagglutinating activity, was named CqLec (Chenopodium quinoa Lectin). After its purification, the CqLec yield was 9.3\% (Table 1).

\section{Hemagglutinating activity determination}

The hemagglutinating activity was tested on intact and trypsinized $\mathrm{ABO}$ system human erythrocytes, observing, at the end of the incubation period, the minimum concentration of lectin isolated from C. quinoa seeds with hemagglutinating activity. The tests showed that the isolated CqLec agglutinates human erythrocytes, having a higher specificity for B Type (Table 2), followed by $\mathrm{A}$ and $\mathrm{O}$.

\section{Test for carbohydrate affinity}

The specificity of carbohydrate binding for the C. quinoa lectin was investigated using the hemagglutinating inhibition method. Though this method is semi-quantitative, it provides information regarding various saccharides capabilities that inhibit lectin activity (Nasi et al., 2009). CqLec demonstrated specificity to glucose and mannose (Table 3 ).

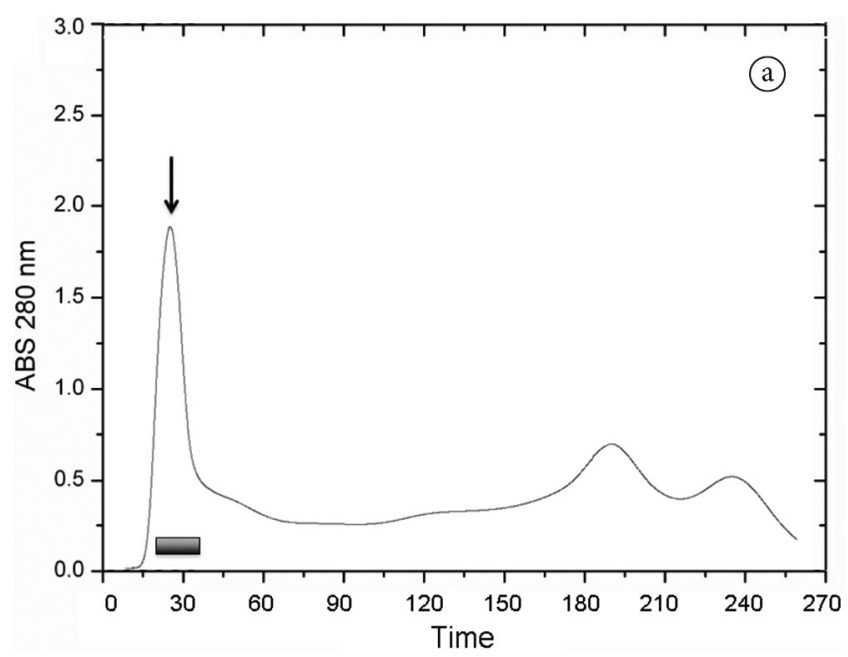

\section{Chelating agents action on the hemagglutinating activity}

The CqLec hemagglutinating activity was shown to be independent of the divalent cations, since EDTA did not inhibit it (not shown).

\section{Denaturing agents action on the hemagglutinating activity}

After being diluted and remaining in buffers at a $\mathrm{pH}$ ranging from between 2 and 10, aliquots of $\mathrm{CqLec}$ underwent a $\mathrm{pH}$ adjustment to a range of between 7 and 8, before being submitted to the hemagglutinating assay. The CqLec activity remained stable even under the wide range of $\mathrm{pH}$ levels (Figure 2a), suggesting great resistance to extreme $\mathrm{pH}$ levels.

The CqLec thermostability was performed by placing the samples at temperatures ranging from between $37^{\circ} \mathrm{C}$ and $100^{\circ} \mathrm{C}$

Table 1. Purification table.

\begin{tabular}{|c|c|c|c|}
\hline Step & $\begin{array}{c}\text { Hemagglutinatting } \\
\text { Activity }\left(\mathrm{HU} .100 \mu \mathrm{L}^{-1}\right)^{\star}\end{array}$ & $\begin{array}{c}\text { Total } \\
\text { Protein } \\
(\mathbf{m g})\end{array}$ & Yield (\%) \\
\hline Crude Extract & 64 & 28.8 & 100.0 \\
\hline Sephadex G50 & 32 & 8.99 & 31.2 \\
\hline MonoQ (GE) & 16 & 0.836 & 9.3 \\
\hline
\end{tabular}

Table 2. Minimum hemagglutinating concentration of CqLec on human erythrocytes.

\begin{tabular}{cc}
\hline $\begin{array}{c}\text { Human Erythrocytes (ABO } \\
\text { system) }\end{array}$ & $\begin{array}{c}\text { Lower hemagglutinating } \\
\text { concentration }(\mu \mathrm{g} / \mathrm{mL})\end{array}$ \\
\hline $\mathrm{A}$ & 7.73 \\
$\mathrm{~B}$ & 3.86 \\
$\mathrm{O}$ & 7.73 \\
$\mathrm{AB}$ & 15.46 \\
\hline
\end{tabular}

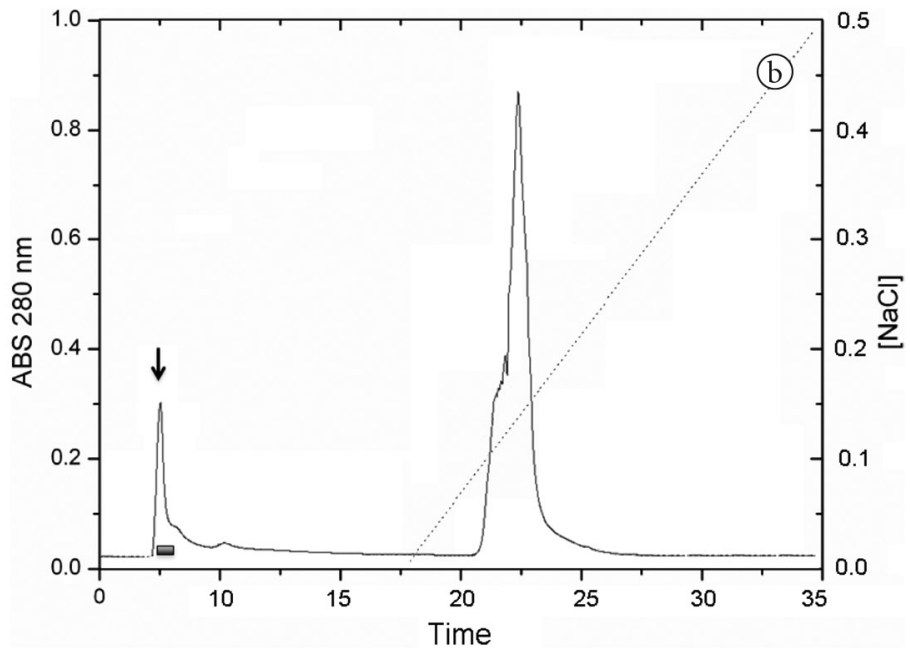

Figure 1. (a) CqCE gel-filtration chromatography column on Sephadex G-50 equilibrated with $0.2 \mathrm{M}$ Ambic buffer at a flow of $0.5 \mathrm{~mL} / \mathrm{min}$; (b) Ion exchange chromatography. The peak originating from the Sephadex G-50 column was applied on a MonoQ resin equilibrated with Tris- $\mathrm{HCl} 20 \mathrm{mM}$ $\mathrm{pH}$ 8.0. The first peak was eluted before the saline solution addition. The second peak has been released after the addition of saline solution. The absorbance was realized at $280 \mathrm{~nm}$. 

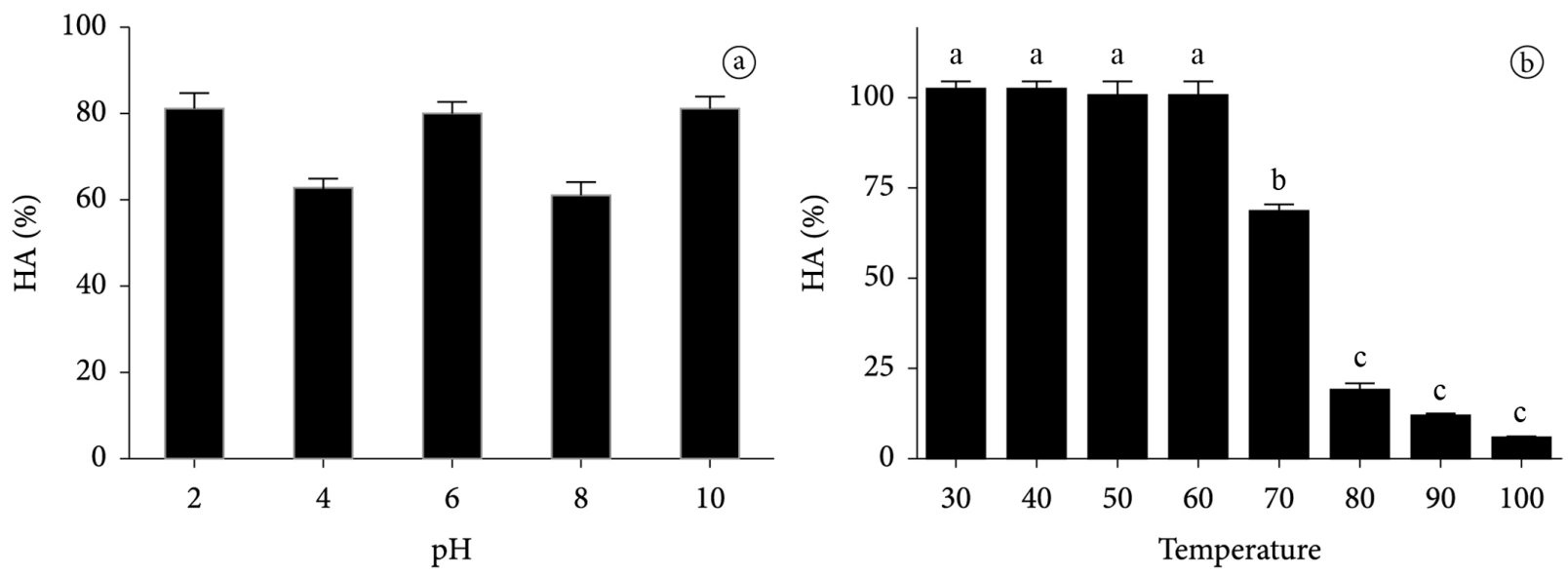

Figure 2. (a) Effect of $\mathrm{pH}$ on hemagglutinating activity of CqLec. Between the treatments no significant difference was found (ANOVA, $<<0.05$ ); (b) Effect of temperature on hemagglutinating activity of CqLec. Different letters represent significant difference between the treatments (ANOVA, $p<0.05)$.

Table 3. Effects of carbohydrates on the hemagglutinating activity induced CqLec.

\begin{tabular}{cc}
\hline Carbohydrates & $\mathrm{MIC}^{*}$ \\
\hline Agar-agar & $\mathrm{NI}^{* *}$ \\
Agarose & $\mathrm{NI}^{* *}$ \\
Corn starch & $\mathrm{NI}^{* *}$ \\
Celullose & $\mathrm{NI}^{* *}$ \\
Fructose & $\mathrm{NI}^{* *}$ \\
Fucose & $\mathrm{NI}^{* *}$ \\
Galactose & $\mathrm{NI}^{* *}$ \\
Glucose & $3.25 \mathrm{mM}^{*}$ \\
Glucosamine & $\mathrm{NI}^{* *}$ \\
Gum arabic & $\mathrm{NI}^{* *}$ \\
Lactose & $\mathrm{NI}^{* *}$ \\
Maltose & $\mathrm{NI}^{* *}$ \\
Mannitol & $\mathrm{NI}^{* *}$ \\
Mannose & $3.25 \mathrm{mM}^{*}$ \\
Methyl $\alpha$ - piranoside & $\mathrm{NI}^{* *}$ \\
Pectin & $\mathrm{NI}^{* *}$ \\
Raffinose & $\mathrm{NI}^{* *}$ \\
Ribose & $\mathrm{NI}^{* *}$ \\
Saccharose & $\mathrm{NI}^{* *}$ \\
\hline
\end{tabular}

${ }^{*}$ MIC: Minimum inhibitory activity. ${ }^{* *}$ No Inhibition.

for 30 minutes. After the sample's temperature returned to ambient temperature, hemagglutinating activity was observed in each. CqLec samples exposed to temperatures of between $37^{\circ} \mathrm{C}$ and $80{ }^{\circ} \mathrm{C}$ demonstrated activity similar to that of the control, while those subjected to $80^{\circ} \mathrm{C}$ lost part of this activity. At temperatures of $100{ }^{\circ} \mathrm{C}$, the sample almost completely lost the activity (Figure 2b).

\subsection{Structural and biochemical characterization of the lectin}

\section{Electrophoresis under denaturing conditions}

The SDS-PAGE showed two bands (Figure 3). The molecular weight of one of the bands was estimated to be $35 \mathrm{kDa}$ and the other band was estimated to be approximately $25 \mathrm{kDa}$.

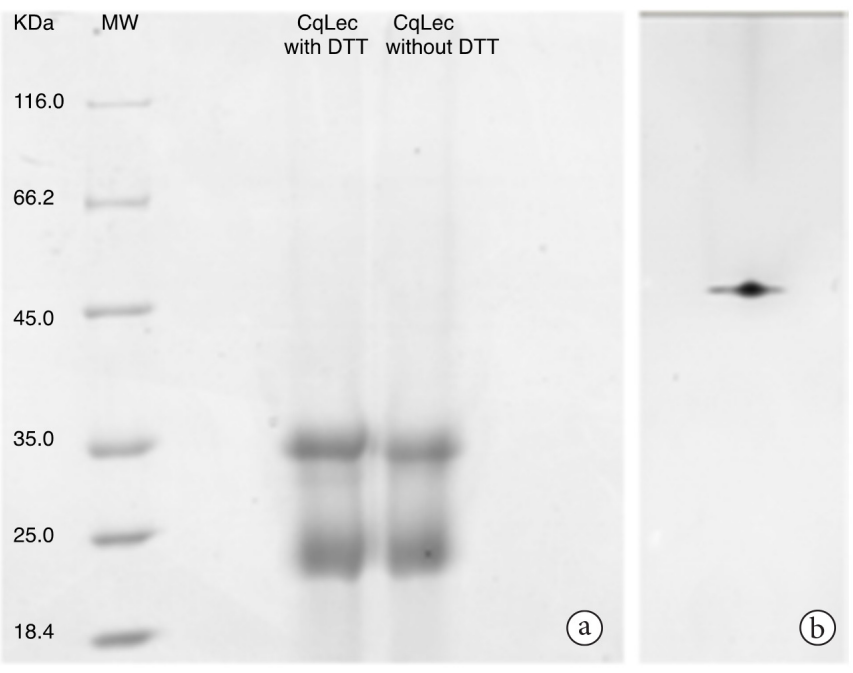

Figure 3. (a) SDS-Page Electrophoresis; (b) Acidic native electrophoresis.

The SDS-PAGEs were made using a sample buffer with DTT with and without the presence of this reagent. No differences could be seen between the two samples, indicating that bisulfide bonds do not link the two distinct subunits of CqLec.

\section{Acidic native electrophoresis}

The purified CqLec showed a single band on the acidic native electrophoresis. Even though the SDS-PAGE demonstrated two bands, the native electrophoresis showed that the CqLec was completely purified and was apparently composed of two subunits with different molecular weights, making it likely that CqLec is probably a heterodimeric lectin of approximately $60 \mathrm{kDa}$.

\subsection{Antimicrobial activity}

The inhibition halos were obtained only on the gram-negative bacteria (Figure 4), specifically, E. coli ATCC 11229, using a CqLec concentration of $500 \mu \mathrm{g} / \mathrm{mL}$ and $250 \mu \mathrm{g} / \mathrm{mL}$, Pseudomonas 

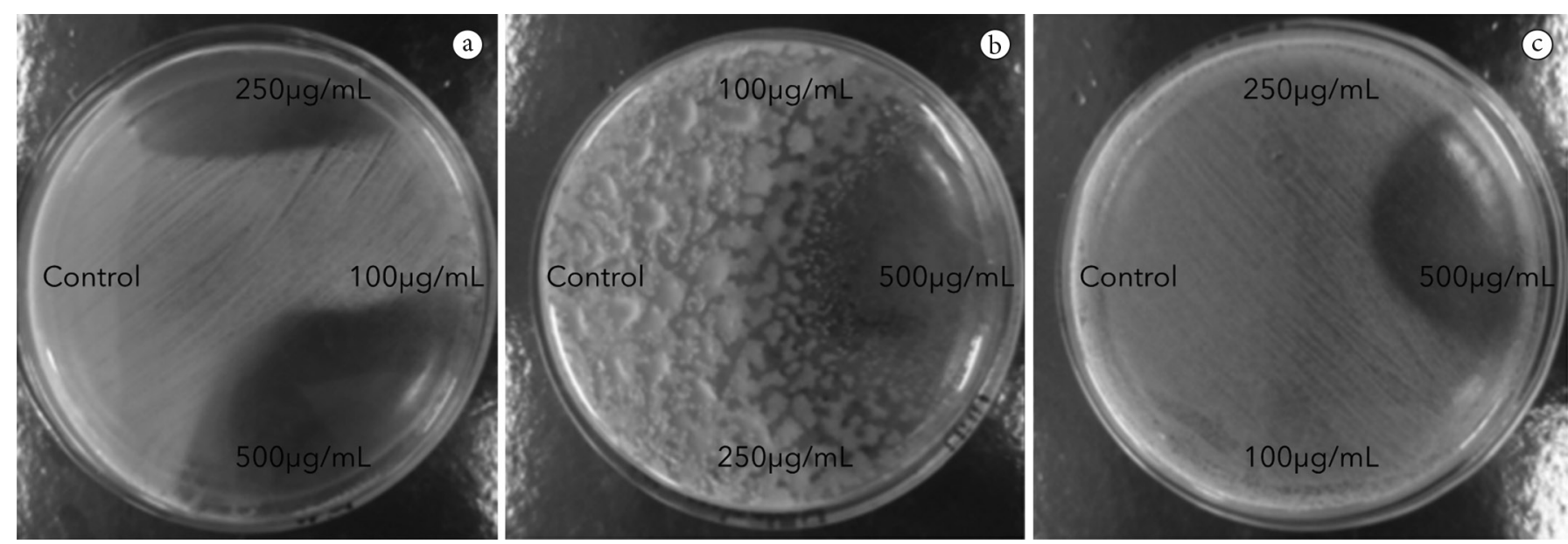

Figure 4. Antimicrobial activity of CqLec. (a) Escherichia coli; (b) Pseudomonas aeruginosa; (c) Salmonella enterica.

aeruginosa ATCC 25619 at a concentration of $500 \mu \mathrm{g} / \mathrm{mL}$ and Salmonella enterica ATCC 10708 at a concentration of $500 \mu \mathrm{g} / \mathrm{mL}$.

\section{Discussion}

Lectins are defined as proteins/glycoproteins that have at least one domain with no catalytic properties that reversibly bind to some mono or oligosaccharides (Van Damme et al., 2003). The specific amino acid residues are essential for maintaining the carbohydrate binding and hemagglutinating activity of the lectins (Baiimiev et al., 2007). The best-known property of lectin activity is erythrocytes hemagglutination. The lectin detection was carried out mainly through the hemagglutination assay. Thus, most researchers have focused their research on human erythrocytes $\mathrm{ABO}$ system antigens.

Some lectins do not agglutinate erythrocytes that are not pretreated with proteases, such as papain and trypsin, which remove obstructions from the membrane surface receptor. This makes them inaccessible to the lectin-binding site. In any case, the interaction of the lectin with the erythrocytes occurs because these receptors are similar to those for which the lectin has specificity. Certainly, the occurrence of lectins points to additional roles and it is appropriate to think of lectins as multifunctional molecules that have more than one function in a particular species or different functions in different species.

The bonding process between lectins and carbohydrates is generally dependent on the presence of metallic ions. The metal's binding site has been described in detail for Con-A, demonstrating that it is very conserved in other plant lectins (Loris et al., 1998). Studies using Castanea crenata lectin (Nomura et al., 1998) demonstrated that this protein is independent of the presence of metallic ions, as is CqLec.

Stability, even under highly acidic and basic conditions, is a common property for lectins. The lectin from quinoa seeds showed stability and kept its activity at a high level when submitted to $\mathrm{pH}$ levels from 2 to 10 . Sharma et al. (2009) obtained similar results when studying lectin, finding considerable stability in the $\mathrm{pH}$ range of 1-14.
Thermal stability is also an interesting property for lectins. The results obtained for CqLec are similar to the lectin that Martínez-Cruz et al. (2001) and Wong et al. (2006) purified and characterized. CqLec is fairly thermostable due to the stability of the hemagglutinating activity between $0{ }^{\circ} \mathrm{C}$ and $80^{\circ} \mathrm{C}$, although it demonstrated a considerable loss in activity level at temperatures of above $90^{\circ} \mathrm{C}$.

Structurally, CqLec was apparently shown to be a heterodimeric lectin, and bisulfide bonds do not link its subunits once the presence and absence of DTT did not show any differences. Similar results were found for JFL and GCL, in which the SDS PAGE, both in the presence and absence of 6-mercaptoethanol JFL, showed two bands with molecular weight $11 \mathrm{kDa}$ and $17 \mathrm{kDa}$, and the GCL showed two bands with molecular weight $17 \mathrm{kDa}$ and $26 \mathrm{kDa}$ (Laija et al., 2010). The lectin from Dioclea lasiophylla seeds is another example of lectins presenting bands of different molecular weights. DlyL is composed of three different chains with different molecular weights and no bisulfide bonds present (Pinto-Júnior et al., 2013).

Several lectins present antibacterial activity. Some studies demonstrated that components of the bacterial cell wall, such as lipopolysaccharides (LPS), peptidoglycans and teichuronic and teichoic acids, are responsible for the antibacterial effects of lectin (Klafke et al., 2013). In the other hand, A. jiringa seed lectin presented higher levels of antimicrobial activity against gram-positive bacteria than against gram-negative bacteria (Charungchitrak et al., 2010), demonstrating that lectin acts against all bacteria groups. These abilities are important tools for biotechnology.

In gram-negative bacteria, the interaction between lectins and LPS is especially interesting, and according to these results, we can infer that bacterial species that have suffered growth interference from CqLec have, in their LPS composition, one or more of the sugars for which the lectin showed specificity. The (sugar) cores of E. coli and S. enterica, for example, are composed of the common hexoses, glucose, galactose, and $\mathrm{N}$ - acetylglucosamine (Klafke et al., 2013), two of which are CqLec-specific. The concentration needed for bacterial growth inhibition by CqLec is similar to those presented by Indigofera 
heterantha lectin (Qadir et al., 2013) and by Canavalia ensiformis lectin (Kulkarni \& Tayade, 2013).

\section{Conclusion}

The evaluation of the results demonstrates that the lectin present in Chenopodium quinoa seeds is probably a heterodimeric protein with a total molecular mass of approximately $60 \mathrm{kDa}$ (one subunit of approximate $25 \mathrm{kDa}$ and another one of 35 $\mathrm{kDa}$ ). In addition, bisulfide bonds are not important for the linkage of these subunits. The evaluation can also verify that CqLec agglutinates type B human erythrocytes at a greater intensity compared to the other blood types. CqLec is resistant to different temperature and $\mathrm{pH}$ ranges, demonstrating its independence to the presence of divalent cations for the activity. The sugar specificity pattern shows that this lectin belongs to the glucose/mannose-binding group. It demonstrated antimicrobial activity against three gram-negative bacteria (Pseudomonas aeruginosa, Escherichia coli and Salmonella enterica), probably due to their specific bond to sugars that are present at the LPS of those bacteria. The present study demonstrated the potential of C. quinoa lectin as an antimicrobial and biotechnological tool.

\section{References}

Ahmad, P., Ashraf, M., Younis, M., Hu, Y., Kumar, A., Akram, N., \& Al-Qurainy, F. (2011). Role of transgenic plants in agriculture and biopharming. Biotechnology advances, 30(3), 524-540. PMid:21959304.

Araújo-Filho, J. H., Vasconcelos, I. M., Martins-Miranda, A. S., Gondim, D. M., \& Oliveira, J. T. (2010). ConA-like lectin from Dioclea guianensis Benth. has antifungal activity against Colletotrichum gloeosporioides, unlike Its homologues, ConM and ConA. Journal of Agricultural and Food Chemistry, 58(7), 4090-4096. http://dx.doi. org/10.1021/jf903254b. PMid:20201549.

Arlinghaus, F. T., \& Eble, J. A. (2012). C-type lectin-like proteins from snake venoms. Toxicon, 60(4), 512-519. http://dx.doi.org/10.1016/j. toxicon.2012.03.001. PMid:22781131.

Baiimiev, A. K., Gubaĭdullin, I. I., Bămiev, A. Kh., \& Chemeris, A. V. (2007). Site-directed mutagenesis of sugar-binding lectin fragments of legume plants with the help of inverse-PCR. Molekuliarnaia Biologiia, 41(5), 940-942. PMid:18240577.

Bhargava, A., Shukla, S., \& Ohri, D. (2006). Chenopodium quinoa: an Indian perspective. Industrial Crops and Products, 23(1), 73-87. http://dx.doi.org/10.1016/j.indcrop.2005.04.002.

Bradford, M. M. (1976). A rapid and sensitive method for the quantitation of microgram quantites of protein utilizing the principle of proteindye binding. Analytical Biochemistry, 72(1), 248-254. http://dx.doi. org/10.1016/0003-2697(76)90527-3. PMid:942051.

Charungchitrak, S., Petsom, A., Sangvanich, P., \& Karnchanatat, A. (2010). Antifungal and antibacterial activities of lectin from the seeds of Archidendron jiringa Nielsen. Food Chemistry, 126(3), 1025-1032. http://dx.doi.org/10.1016/j.foodchem.2010.11.114.

Coelho, M. B., Macedo, M. L., Marangoni, S., Silva, D. S., Cesarino, I., \& Mazzafera, P. (2010). Purification of Legumin-like proteins from Coffea arabica and Coffea racemosa seeds and their insecticidal properties toward Cowpea Weevil (Callosobruchus maculatus) (Coleoptera: Bruchidae). Journal of Agricultural and Food Chemistry, 58(5), 3050-3055. http://dx.doi.org/10.1021/jf9037216. PMid:20141142.

Ghosh, G., \& Mandal, D. K. (2012). Differing structural characteristics of molten globulin intermediate of peanut lectin in urea and
guanidine-HCl. International Journal of Biological Macromolecules, 51(3), 188-195. http://dx.doi.org/10.1016/j.ijbiomac.2012.05.010. PMid:22595796.

Goldstein, I. J., \& Poretz, R. D. (1986). Isolation, physicochemical characterization, and carbohydrate-binding specificity of lectins. In I. E. Liener, N. Sharon \& I. J. Goldstein. The lectins: properties, functions, and applications in biology and medicine. Orlando: Academic Press.

Kamiya, Y., Satoh, T., \& Kato, K. (2012). Molecular and structural analysis for $\mathrm{N}$-glycon-dependent determination of glycoprotein fates in cells. Biochimica et Biophysica Acta, 1820(9), 1327-1337. http://dx.doi.org/10.1016/j.bbagen.2011.12.017. PMid:22240168.

Klafke, G. B., Borsuk, S., Gonçales, R. A., Arruda, F. V., Carneiro, V. A., Teixeira, E. H., Silva, A. L. C., Cavada, B. S., Dellagostin, O. A., \& Pinto, L. S. (2013). Inhibition of initial adhesion of oral bacteria through a lectin from Bauhinia variegata $\mathrm{L}$. var. variegata expressed in Escherichia coli. Journal of Applied Microbiology, 115(5), 1222-1230. http://dx.doi.org/10.1111/jam.12318. PMid:23910219.

Kulkarni, S. R., \& Tayade, V. J. (2013). Bacteriostatic activity of con a lectin from Canavalia ensiformis. Indian Journal of Pharmaceutical and Biological Research, 1(4), 59-63.

Laija, S. N., Mahesh, S., Smitha, L. S., \& Remani, P. (2010). Isolation and partial characterization of two plant lectins. Current Research Journal of Biological Science, 2(4), 232-237.

Lee, R. S., \& Peng, K. Y. (2012). Synthesis of glycopoly(pseudo amino acids) and their interaction with lectins. Reactive \& Functional Polymers, 72(9), 564-573. http://dx.doi.org/10.1016/j.reactfunctpolym.2012.06.003.

Loris, R., Hamelryck, T., Bouckaert, J., \& Wyns, L. (1998). Legume lectin structure. Biochimica et Biophysica Acta, 1383(1), 9-36. http://dx.doi. org/10.1016/S0167-4838(97)00182-9. PMid:9546043.

Lundbo, L. F., Sørensen, H. T., Clausen, L. N., Hollegaard, M. V., Hougaard, D. M., Konradsen, H. B., Harboe, Z. B., Nørgaard, M., \& Benfield, T. (2015). Mannose-binding lectin gene, MBL2, polymorphisms do not increase susceptibility to invasive meningococcal disease in a population of Danish children. Open Forum Infectious Diseases Advance Acess, 2(4), ofv127. http://dx.doi.org/10.1093/ofid/ofv127. PMid:26464842.

Martínez-Cruz, M., Zenteno, E., \& Córdoba, F. (2001). Purification and characterization of a galactose-specific lectin from corn (Zea mays) coleoptile. Biochimica et Biophysica Acta, 1568(1), 37-44. http://dx.doi.org/10.1016/S0304-4165(01)00196-9. PMid:11731083.

Molina, J., Landa, A., Bautista, G., Martinez, M., \& Cordoba, F. (2004). Molecular association of lectin and h-glucosidase in corn coleoptile. Biochimica et Biophysica Acta, 1674(3), 299-304. http://dx.doi. org/10.1016/j.bbagen.2004.07.002. PMid:15541299.

Nasi, A., Picariello, G., \& Ferranti, P. (2009). Proteomic approaches to study structure, functions and toxicity of legume seeds lectins perspectives for the assessment of food quality and safety. Journal of Proteomics, 72(3), 527-538. http://dx.doi.org/10.1016/j.jprot.2009.02.001. PMid:19217948.

Nomura, K., Ashida, H., Uemura, N., Kushibe, S., Ozaki, T., \& Yoshida, M. (1998). Purification and characterization of a mannose/glucosespecific lectin from Castanea crenata. Phytochemistry, 49(3), 667-673. http://dx.doi.org/10.1016/S0031-9422(97)00924-2. PMid:9779592.

Oliveira, M. R. T. R., Napimoga, M. H., Cogo, K., Gonçalves, R. B., Macedo, M. L. R., Freire, M. G. M., \& Groppo, F. C. (2007). Inhibition of bacterial adherence to saliva-coated through plant lectins. Journal of Oral Science, 49(2), 141-145. http://dx.doi.org/10.2334/ josnusd.49.141. PMid:17634727.

Pesoti, A. R., Oliveira, B. M., Oliveira, A. C., Pompeu, D. G., Gonçalves, D. B., Marangoni, S., Silva, J. A., \& Granjeiro, P. A. (2015). Extraction, 
purification and characterization of inhibitor of trypsin from Chenopodium quinoa seeds. Food Science and Technology. In press. http://dx.doi.org/10.1590/1678-457X.6655.

Pinto-Júnior, V. R., Santiago, M. Q., Osterne, V. J. S., Correia, J. L. A., Pereira, F. N. Jr., Cajazeiras, J. B., Vasconcelos, M. A., Teixeira, E. H., Nascimento, A. S. F., Miguel, T. B. A. R., Miguel, E. C., Sampaio, A. H., Nascimento, K. S., Nagano, C. S., \& Cavada, B. S. (2013). Purification, partial characterization and immobilization of a mannose-specific lectin from seeds of Dioclea lasiophylla mart. Molecules, 18(9), 10857-10869. http://dx.doi.org/10.3390/ molecules180910857. PMid:24008245.

Qadir, S., Wani, I. H., Rafiq, S., Ganie, S. A., Massod, A., \& Hamid, R. (2013). Evaluation of antimicrobial activity of a lectin isolated and purified from Indigofera heterantha. Advances in Bioscience and Biotechnology, 4(11), 999-1006. http://dx.doi.org/10.4236/ abb.2013.411133.

Sharma, A., Ng, T. B., Wong, J. H., \& Lin, P. (2009). Purification and characterization of a lectin from Phaseolus vulgaris cv. (Anasazi Beans). Journal of Biomedicine \& Biotechnology, 929568, 9. PMid:19343172.

Sharon, N. (2008). Lectins: past, present and future. Biochemical Society Transactions, 36(6), 1457-1460. http://dx.doi.org/10.1042/ BST0361457. PMid:19021575.

Sharon, N., \& Lis, H. (1972). Lectins: cell-agglutinating and sugar-specific proteins. Science, 177(4053), 949-959. http://dx.doi.org/10.1126/ science.177.4053.949. PMid:5055944.

Silva, J. A., Damico, D. C., Baldasso, P. A., Mattioli, M. A., Winck, F. V., Fraceto, L. F., Novello, J. C., \& Marangoni, S. (2007). Isolation and biochemical characterization of a galactoside binding lectin from Bauhinia variegata candida (BvcL) seeds. The Protein Journal, 26(3), 193-201. http://dx.doi.org/10.1007/s10930-006-9061-0. PMid:17203390.

Silva, J. A., Pompeu, D. G., Costa, O. F., Gonçalves, D. B., Spehar, C. R., Marangoni, S., \& Granjeiro, P. A. (2015). The importance of heat against antinutritional factors from Chenopodium quinoa seeds. Food Science and Technology, 35(1), 74-82. http://dx.doi. org/10.1590/1678-457X.6427.

Van Damme, E. J. M., Lannoo, N., Fouquaert, E., \& Peumans, W. J. (2003). The identification of inducible cytoplasmic/nuclear carbohydratebinding proteins urges to develop novel concepts about the role of plant lectins. Glycoconjugate Journal, 20(7-8), 449-460. http:// dx.doi.org/10.1023/B:GLYC.0000038291.67527.a5. PMid:15316278.

Visini, R., Jin, X., Bergmann, M., Michaud, G., Pertici, F., Fu, O., Pukin, A., Branson, T. R., Thies-Weesie, D. M. E., Kemmink, J., Gillon, E., Imberty, A., Stocker, A., Darbre, T., Pieters, R. J., \& Reymond, J. L. (2015). Structural insight into multivalent galactoside binding to pseudomonas aeruginosa Lectin LecA. ACS Chemical Biology. In press. http://dx.doi.org/10.1021/acschembio.5b00302. PMid:26295304.

Wong, J. H., Chan, H. Y. E., \& Ng, T. B. (2008). A mannose/glucosespecific lectin from Chinese evergreen chinkapin (Castanopsis chinensis). Biochimica et Biophysica Acta, 1780(9), 1017-1022. http:// dx.doi.org/10.1016/j.bbagen.2008.05.007. PMid:18570898.

Wong, J. H., Wong, C. C. T., \& Ng, T. B. (2006). Purification and characterization of a galactose-specific lectin with mitogenic activity from pinto beans. Biochimica et Biophysica Acta, 1760(5), 808-813. http://dx.doi.org/10.1016/j.bbagen.2006.02.015. PMid:16600511. 